\title{
Comparative Study on the Effect of Citrillus lanatus and Cucumis sativus on the Growth Performance of Archachatina marginata
}

\author{
Ufele Angela Nwogor \\ Zoology Department, Nnamdi Azikiwe University, Awka, Nigeria
}

\section{Email address:}

ufeleangel@yahoo.com

To cite this article:

Ufele Angela Nwogor. Comparative Study on the Effect of Citrillus lanatus and Cucumis sativus on the Growth Performance of Archachatina marginata. American Journal of Agriculture and Forestry. Vol. 3, No. 4, 2015, pp. 135-139. doi: 10.11648/j.ajaf.20150304.13

\begin{abstract}
Feeding accounts for a reasonable percentage of the cost of livestock production and a major factor that determines the viability and profitability of livestock farming ventures. Also scarcity and high cost of meat for human consumption has necessitated the need for intensive rearing of some non-conventional livestock such as the snail hitherto hunted from the wild, in view of this, this study evaluated the effects of two fruits, Cucumber (Cucumis sativus) and Watermelon (Citrillus lanatus) on the growth performance of Archachatina marginata. The study was conducted using One hundred and thirty five (135) snails, 15 snails per treatment and each treatment was replicated three times and the experiment lasted for a period of eight weeks. In terms of growth, results showed that the snails fed with watermelon and cucumber performed generally better than others but statistically, no significant difference $(\mathrm{P}>0.05)$ existed between the snails (in terms of weight, length, circumference of the snail) fed with the two fruits and the combination of both. From the result, it was observed that the mean weight gain of snails fed with Citrillus lanatus ( Cage A) was 5.43g, those fed with Cucumis sativus (Cage B) had mean weight gain of $1.22 \mathrm{~g}$, while those fed with both fruits (Cage C) had 7.53g. The mean shell length increase in snails fed with Citrillus lanatus was $10.74 \mathrm{~mm}$, those of Cucumis sativus was $10.52 \mathrm{~mm}$, while those fed with both had $12.24 \mathrm{~mm}$. The mean shell circumference of snails fed with Citrilus lanatus was $14.47 \mathrm{~mm}$, those fed with Cucumis sativus had $14.15 \mathrm{~mm}$, while those fed with both had $15.16 \mathrm{~mm}$. From the results, snails fed with both Citrillus lanatus and Cucumis sativus performed best while snails fed with Citrillus lanatus performed better than those fed with Cucumis sativus in all parameters measured. Therefore, snail farmers are advised to use the combination of cucumber and watermelon for a better yield.
\end{abstract}

Keywords: Snails, Growth Performance, Cucumber (Cucumis sativus), Watermelon (Citrillus Lanatus)

\section{Introduction}

The scarcity and high cost of meat for human consumption has necessitated the need for intensive rearing of some nonconventional livestock such as the snail hitherto hunted from the wild (Alikwe et al., 2014). The low capital and simple management practices involved have also drawn the attention of many farmers to snail farming (Mogbo et al., 2013). Snail meat is often regarded as a form of bush meat or game meat to be eaten occasionally instead of being a nutritious meat to be relished on a daily basis just like the meat of other conventional livestock (Malik and Dikko, 2009). Snail meat often referred to as Congo meat is a high quality food rich in protein, low in fats and source of iron (Orisawuyi, 1989) calcium, magnesium and zinc (Ademolu et al., 2004). Imevbore and Ademosun (1988) accessed the nutritional value of snail and observed that it has a protein content of $88.37 \%$ which compares favourably with conventional animal protein sources. Adeyeye (1996) noted that snails contain almost all the amino acids required by man. Its tenderness and fine texture makes it the most suitable for all ages (Okonta, 2012). The low content of fat (1.3\%) and low cholesterol level make snail a good antidote for vascular diseases such as heart attack, cardiac arrest, hypertension, stroke, high blood pressure and other fat related ailments (Akannusi, 2002). Other curable ailments by snails in Nigeria include whooping cough, anaemia, ulcer, asthma, age problems, hypertension and rheumatism (Abere and Lameed, 2008). The meat content of snails has been reported to cause reduction in the labour pain and loss of blood during labour, restoration of virility and fertility in human beings (Agbogidi et al., 2008). Imevbore and Ademosun, (1988) also 
maintained that the serotonin secreted in the snail's body is effective in the maintenance of normal behavior after mental depression. Not only is the flesh of snail a valued delicacy, but the shells and offal have also gained considerable value in the manufacturing of feed for animals of different types (Ayodele and Ashimolowo, 1999). According to Cobbinah et al.,(2008), crushed snail shells may be applied in chicken feed or liming to improve the quality of acidic (fish pond) soil.

In view of the high quality of protein obtained from snails, they have secured high demand in many cuisines both locally and internationally (Ngenwi et al., 2010). The popularity of giant land snails in the world is increasingly reduced by indiscriminate hunting and deforestation which destroys the snail habitat, therefore rearing of the giant land snails as a domestic animal would therefore help in some measure to satisfy the demand for the meat and to ensure the survival of the species (Ademolu et al., 2004). Usually, snails become scarce during the dry season hence expensive at this period (Amusan, 2002) their domestication could make them more readily available all year round as well as reduce their prices to a reasonable extent (Okonta, 2012). Awah (1992) said that Archachatina marginata feed on a wide variety of feed including both fruits and leaves of plants.

Cucumis sativus (cucumber) and Citrillus lanatus (watermelon) are fruits with high water content. They belong to the family Cucurbitaceae. They are readily available in Nigeria especially during the wet season. These fruits were used for this experiment in accordance to Amata,( 2014), who stated that moisture content of snails feed is usually very high because of the method of feeding by snails which prefer feed in fluid.

Snail farming is one of the most lucrative and prolific farming in recent times (Ufele et al., 2013). This has raised the interest of improving the culturing and rearing of snails within Nigeria to increase protein intake through eating snail

meat (Ufele et al., 2013). Snail farming is also a tool for poverty alleviation (Moyin-jesu and Ajao 2008).

\section{Materials and Methods}

\subsection{Procurement of Experimental Animal}

One hundred and thirty five adult snails of the specie Archachatina marginata of average weight $102.5 \mathrm{~g}$ were used for the experiment. The snails were allowed to acclimatize in their new environment for one week before the commencement of the experiment.

\subsection{Experimental Treatments}

One hundred and thirty five adult snails were used for the study and the experiment lasted for a period of eight weeks. The snails were randomly grouped into three of fifteen snails per group and were assigned to three dietary treatments. Treatment one was fed with Watermelon (Citrillus lanatus), Treatment two was fed with Cucumber (Cucumis sativus), while Treatment three was fed with both cucumber and watermelon. Each treatment was replicated three times. The snails were measured on weekly basis and parameters measured were length, shell circumference and weight. The snails were measured individually.

\subsection{Data Analysis}

The length, shell circumference and weight of the snails were taken weekly using a sensitive weighing balance and caliper. The result of the experiment was analyzed using Analysis of variance (ANOVA). The comparison of mean was separated using a post Hoc test (Least Significant Difference), (William and George, 2008).

\section{Results}

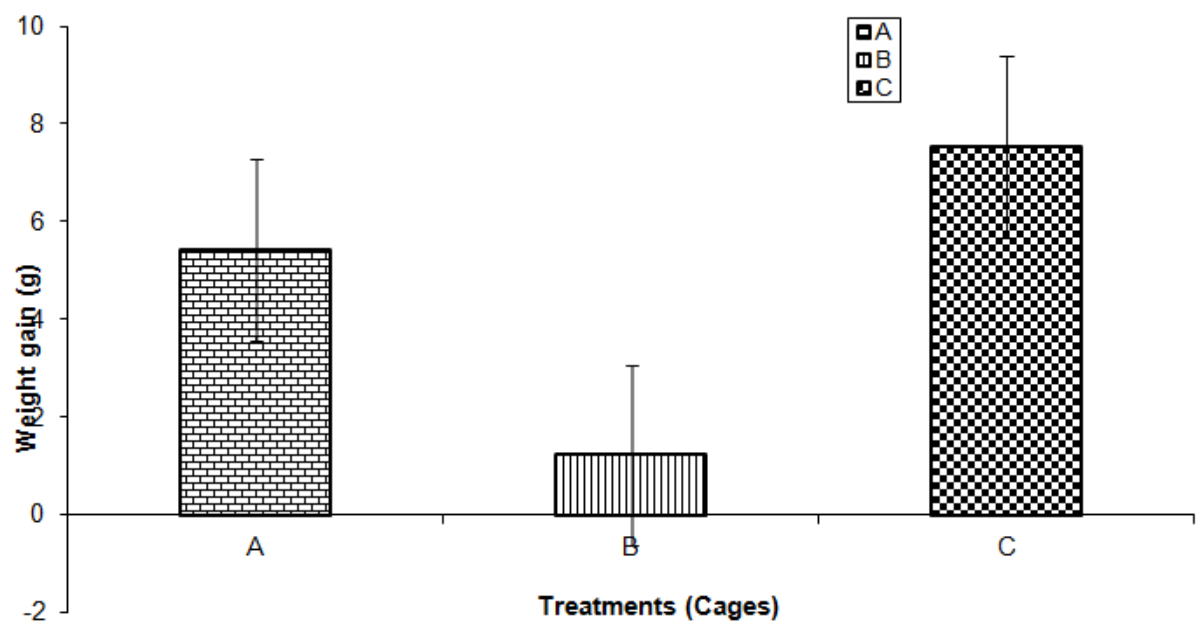

Figure 1. Mean Weight gain of snails.

Figure 1 shows the mean weight of snails fed with different treatments. From the result it was observed that snails fed with combination of Cucumber (Cucumis sativus) and Watermelon (Citrillus lanatus) (Cage C) had the highest mean weight (7.53g). Followed by those fed with Watermelon (Citrillus lanatus) (Cage A) (5.43g) and those 
fed with Cucumber (Cucumis sativus) (Cage B) had the lowest mean weight gain (1.22g).

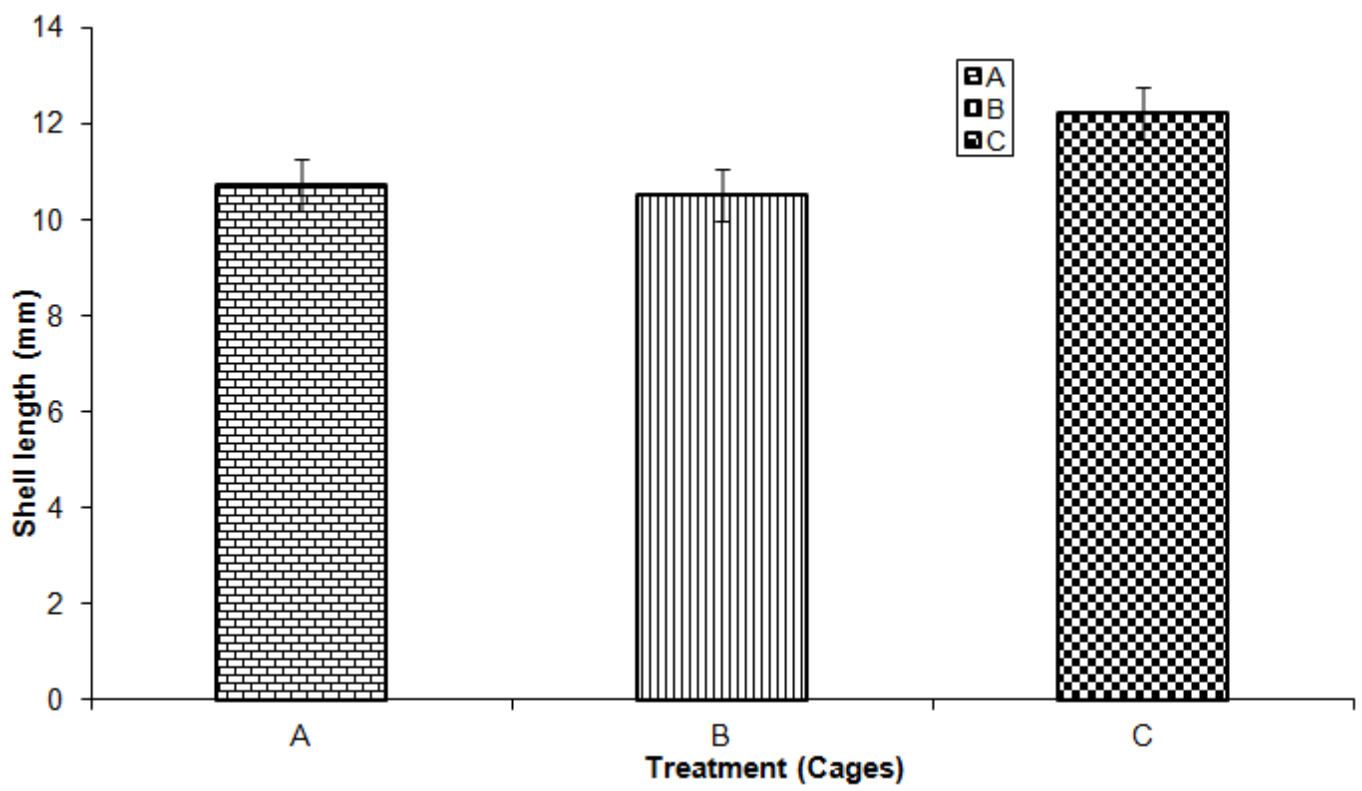

Figure 2. Shell length of snails.

Figure 2 shows the shell length increase of the snails fed with different treatments. From the figure it was observed that snail fed with combination of Cucumber (Cucumis sativus) and Watermelon (Citrillus lanatus) (Cage C) had the highest increase in the shell length $(12.24 \mathrm{~mm})$. Followed by those fed with Watermelon (Citrillus lanatus) (Cage A) $(10.74 \mathrm{~mm})$ and those fed with Cucumber (Cucumis sativus) (Cage B) had the lowest increase in the shell length $(10.52 \mathrm{~mm})$.

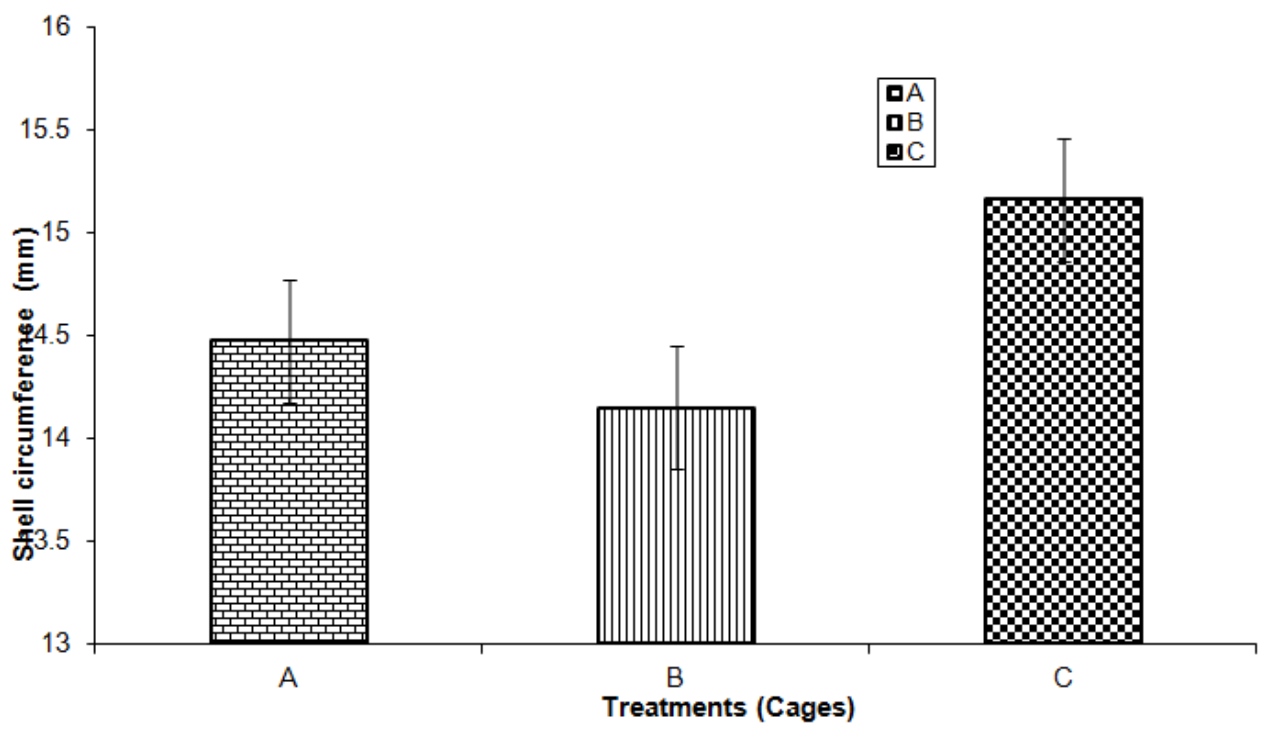

Figure 3. Shell Circumference of snails.

Figure 3 shows the shell circumference of snails fed with different treatments. From the result of Figure 3, it was observed that snails fed with combination of Cucumber (Cucumis sativus) and Watermelon (Citrillus lanatus) (Cage C) had the highest increase in the shell circumference $(15.16 \mathrm{~mm})$. Followed by those fed with Watermelon (Citrillus lanatus) (Cage A) $(14.47 \mathrm{~mm})$ and those fed with Cucumber (Cucumis sativus) (Cage B) had the lowest increase in the shell circumference $(14.15 \mathrm{~mm})$.

\section{Discussion}

From the results above, it is observed that both feeds have positive impact on the growth performance of the experimental animal. It was observed that snails fed with combination of both fruits (Cage C) performed best, followed by those fed with watermelon (Cage A). While those fed with cucumber had the least performance, though statistically, there was no significant difference in the growth performance 
of the snails in all the treatments $(p<0.05)$. This result is in accordance to Alexander (1997) who stated that food attractiveness is important in snail's nutrition; if the food is appetizing the snails will eat a lot and grow quickly. There was no significant difference in the growth performance of the snails fed with the three treatments, this might be as a result that the two fruits belong to the same family and have almost same nutritive components. Also, there was increase in both length and circumference of the snail. As the body weight increased, there seemed to be increase in size probably due to expansion of the shell. This observation is consistent with the finding of Omole et al., (1999) who noted an increase in the length and circumference of land snail fed on fruits. From the result, the snails in all the treatments increased in both weigth, shell length and shell circumference, this may be attributed to the findings of Ajayi, et al., (1978) who stated that snails are generally heterotrophic animals and feed on a wide variety of young dicotyledonous plants and cultivated plants. It was also stated that snails are vegetarians and will accept many types of food Snails feed on leaves which may include cocoyam, kola, pawpaw, cassava, okra, egg plant, cabbage, lettuce. They also feed on fruits like pawpaw, mango, banana, egg plant, pear, oil palm, fig, tomato, cucumber which are rich in vitamins and minerals (Akinnusi, 1998). In another research it was also discovered that the younger snail appear to prefer leaves to fruits while older and larger snails would go for fruits when offered a choice between leaves and fruits (Ejidike, 2001). This is in relation to this research.

\section{Conclusion}

In conclusion, the result of this research shows that the snail Archachatina marginata can be fed with cucumber (Cucumis sativus) and watermelon (Citrillus lanatus) since the snails enjoy it and it had positive effect on their growth performance, it is better to combine the two fruits for a better yield. Snail farmers are advised to feed their snails with cucumber and watermelon.

\section{References}

[1] Abere, S.A. and Lameed, G.A. (2008). The Medicinal Utilization of Snails in Some Selected States in Nigeria. Proceeding of the First National Conference of the Forest and Forest Products Society (FFPs). pp. 233-237.

[2] Ademolu, K. O., Idowu, A. B., Matiana, C. F. and Osinowo, O. A. (2004). Performance proximate and mineral analysis of African giant land snail (Archachatina marginata) fed different nitrogenous sources. African Journal of Biotechnology 3 (8): 412 - 417.

[3] Adeyeye, E.I. (1996). Waste yield, Proximate and mineral Composition of three different types of land snail found in Nigeria. International Journal of Food Science and Nutrition 42(2): 111-116.

[4] Agbogidi, O.M. Okonta, B.C. and Ezeani, E.L. (2008) Effects of two edible fruits on the growth performance of African giant land snail, (Archachatina marginata). Journal of Agricultural and Biological Sciences 3 (3): 26- 29.

[5] Ajayi, S. S, Tewe, O. O., Moriarty, C. and Awesu, M. O. (1978): Observation on the Biology and Nutritive Value of African Giant Snail (Archachatina marginata). East African Wildlife Journal. 16:85 - 95.

[6] Akinnusi, O. (1998). A Practical Approach to Back Yard Snail Farming. Nigerian Journal of Animal Production. 25:193197.

[7] Akinnusi, O. (2002). Introduction to snail and snail farming. Triolas Exquisite ventures. Abeokuta. 25pp.

[8] Alexander, B.O. (1997). Snails and Snail Farming (Nigeria Edible Land Snails). University Publishers Ibadan. Pp 1-65.

[9] Alikwe, P.C.N, Yeigba, J., Akinnusi, B., Oyenike, F.A, Ohimain, E.I (2014). Performance and carcass characteristics of Giant African Land Snails fed Alchornea cordifolia leaf meal in replacement for soybean meal. International Journal of Research in Agriculture and Food Sciences. 1(6):1-4.

[10] Amata, I.A. (2014). Effects of Microhabitat on the Egg Hatchability and Hatchling Growth Performance of the Giant African Land Snails (Archachatina marginata). Global Journal of Biology, Agriculture and Health Sciences. 3(2):2731 .

[11] Amusan, O.M. (2002). The techniques of snail farming as a viable and profitable venture. Oak Ventures Publishers, Lagos. $23 \mathrm{pp}$

[12] Awah, A.A. (1992). Snail Farming in mature Rubber Plantation: Studies on the aspect of specialized Production Techniques of farming Archachatina marginata: Snail Farming Research 4: 33-39

[13] Ayodele, I.A, and Asimalowo, A.A (1999). Essentials of snail farming. Agape Prints, U.I, Ibadan, p. 51.

[14] Cobbinah, J.R, Vink, A., Onwuka, B. (2008). Snail Farming: Production, processing and marketing. Agromisia Foundation, Wageningen. First Edition 78pp.

[15] Ejidike. B. N. (2001) Comparative effect of supplemental and complete diets on the performance of African giant land snail ( A. marginata). Proceedings of the 26th Annual Conference of the Nigerian Society for Animal Production. 26: 151 - 153.

[16] Imevbore, E. and Ademosun, A. A. (1988). The nutritive value of African Giant land snail (Archachatina marginata). Nigerian Journal of Animal Production. 15: 109 - 112.

[17] Malik, A.A. and Dikko, A.H. (2009). Heliculture in Nigeria, the potentialities, opportunities and challenges (a review). Proceedings of the $34^{\text {th }}$ Annual Conference of Nigerian Society for Animal Production. Pp 120-1124.

[18] Mogbo, T.O, Okeke, J.J, Ufele, A.N, Nwosu, M.C, Ibemenuga, K.N (2013). Preliminary investigation on the influence of housing types on reproductive characteristics of snail (achatina achatina). American journal of bioscience. 1(4):5458 .

[19] Moyin-Jesu, E.I, and Ajao, K. (2008). Raising of giant snails (Archachatina marginata) in urban cities using soil amendments and feeding materials for food security. African Journal of Science and Technology (AJST) Science and Engineering series. 9(1):118-124. 
[20] Ngenwi, A.A, Mafeni, J.M, Etchu, K.A, Oben, F.T (2010). Characteristics of snail farmers and constraints to increased production in West and Central Africa. African Journal of Environmental Science and Technology. 4(5):274-278.

[21] Okonta, B.O. (2012). Performance of Giant African Land Snails Archachatina marginata fed with selected diets. Global Journal of Bioscience and Biotechnology. 1(2):182-185.

[22] Omole, A.J. Oluokun, J.A. Oredein, A.O. Tiomiyu, A.K. Afolabi, A.O. Adetoro, F.O. and Adejuyibe, A.P. (1999) Snail production potential for increasing animal protein intake in West Africa. Proceedings of the 26th annual conference of the
Nigeria Society of Animal Production. Pp. 393-401.

[23] Orisawuyi, Y. A. (1989). Practical guides to snail rearing. Gratitude Enterprises, Lagos. 27pp.

[24] Ufele, A.N, Nnajidenma, U.P., Ebenebe, C.I., Mogbo, T.C., Aziagba, B.O. and Akunne, C.E. (2013). The effect of Azardirachta indica (neem) leaf extract on longevity of Snails (Achatina achatina). International Research Journal of Biological Sciences. 2(1): 61-63.

[25] William, A.C., and George, W.S. (2008). Statistical Methods, $6^{\text {th }}$ Ed., The Iowa State University Press. Ames, Iowa, USA. Pp. 167-263. 